Weight losses at cooking represented 31.6 p. 100 in crossbreds and 30.5 p. 100 in Pietrain. Meat from crossbred animals was more fat and lost more weight, but remained more juicy. Even though the causes of the differences observed are still difficult to explain, several hypotheses may be put forward. The interest of production of «quality » meat by crossing Chinese breeds with our modern breeds is discussed.

\title{
Effects of various physical ireatments on the destabilization of water-protein bonds in pork
}

\author{
B.L. DUMONT, Eléonore HUDZIK \\ I.N.R.A., Laboratoire de Recherches sur la Viande, 78350 Jouy-en-Josas \\ France
}

Samples of Biceps femoris from a group of Pietrain male pigs $(\mathrm{N}=10$ young boars of $100 \mathrm{~kg}$ live weight) were subjected to the following treatments for destabilizing the water-protein equilibrium in the muscle :

A) compression after mincing,

B) home gril cooking,

C) cooking at $80^{\circ} \mathrm{C}, 60$ minutes in a dry atmosphere,

D) cooking at $100^{\circ} \mathrm{C}, 30$ minutes in water,

E) cooking at $105^{\circ} \mathrm{C}, 60$ minutes in salted water.

Weight losses (M) were calculated for the five methods. Dry matter losses (M) and protein losses (MA) were calculated only for B, C, D, E methods.

The losses were variable and the differences highly significant according to methods : for $\mathrm{M}$, from 19.6 (A) to 46.4 (D), for MA, from 0.65 (B) to 2.47 (D), for MS, from 1.97 (B) to 3.81 (D).

Variation between animals depended on the physical methods used and the chemical component considered. Each method seemed to have a specific effect on the water-protein equilibrium in the muscle and led to a different grading of the meat.

\section{Interrelations between some physico-chemical traits of muscles from Pietrain pigs of various conformation}

\author{
J. BOUSSET, B.L. DUMONT \\ I.N.R.A., Laboratoire de Recherches sur la Viande, 78350 Jouy-en-Josas
}

France

Various physico-chemical parameters (TN, SN, sarcoplasmic protein nitrogen, isoenzyme 5 of the LDF, hem iron, $\mathrm{pH}$, water binding capacity, as well as indexes of muscle development (muscle mass (M)/thigh bone mass) were measured in 5 muscles from a group of ten entire male pigs of the Pietrain breed.

Each muscle was characterized by a specific biophysico-chemical profile. Both samples of Longissimus dorsi ( $\mathrm{LD}_{\mathrm{L}, 3}, \mathrm{LD}_{\mathrm{D} 14}$ ) were almost similar and quite different from the Adductor (AD)-Biceps femoris (BF) group : Semimembranosus (SM) was in an intermediate position, but closer to Longissimus dorsi.

Multidimensional analyses using the method of centred data showed that the relationships between variables were almost similar for each muscle and that within the muscle, the composition was determined by the antagonisms between iron, the different forms of nitrogen and the proportion of the isoenzyme 5 .

Whatever the muscle, effects of variations in the relative development of muscles were similar. Improvement in conformation led to a paler meat, with a lower $\mathrm{pH}$ and a lower water binding capacity. 